International Journal of Engineering \& Technology, 7 (3.30) (2018) $489-496$
International Journal of Engineering \& Technology
Website $:$ www.sciencepubco.com/index.php/IJET
Research paper

\title{
Determination of Free Trade Zone and Free Port Development Area Development in Batam City, Riau Islands, Indonesia
}

\author{
Edi Indera $^{1} *$, Marlon Sihombing ${ }^{2}$, Chairul Muluk $^{3}$, Rujiman $^{4}$, and Chablullah Wibisono ${ }^{5}$ \\ ${ }^{1}$ Program Doctor of Regional Planning, Graduate School University of North Sumatra, Medan, Indonesia \\ ${ }^{2}$ Faculty of Social and Political Sciences, University of North Sumatra, Indonesia \\ ${ }^{3}$ Faculty Economi University of North Sumatera, Indonesia \\ ${ }^{4}$ Faculty Economi University of North Sumatera, Indonesia \\ ${ }^{5}$.Faculty Economi University of Batam, Indonesia \\ *Corresponding Author Email: chablullahwibisono@gmail.com
}

\begin{abstract}
Batam Island is built into the Free Trade since 1970 by the Batam Authority, but in 2000 stood Batam City Government, to 2016 the economy grew $6,5 \%$, but since 2017 dropped to $2 \%$, this phenomenon should be a study. The population is employee environment Batam Area Concession Agency, APINDO, BKPM, Batam City Government Employees, the Chamber of Commerce, Community and students. Total respondents 190 respondents sampled (census method). Data Analysis was perfomed using Structural Equation Model (SEM). The software used for the structural analysis is AMOS 22, descriptive analysis using SPSS version 22.0. Geographical Utilization variable determination to variable investmenthas standardized estimate of $0,121<0,50$ with $\mathrm{CR}$ identical to the value $\mathrm{t}$-tes) $\mathrm{CR}=1,749<2,00$ on probability $=0,080>0,05$ is negative not significant. Determination variable to variable Infrastructure Investmenthas standardized estimate 0 f $-0,816<0,50$ with CR identical to the value $t$-test $=-2,013<2,00$ on probability $=0,044<0,05$ is significantly negative. Determination of laten variable to variable organizations Resource investment has standardized estimate of 0,972>0,50 with CR identical to the value $\mathrm{t}$ count $=7,336>2,00$ on probability $=* * *<0,05$ is a significant positive. Utilization variable determination to variable Geographical Area Developmenthas standardized estimate of $0,020<0,50$ with CR idential to value $t$ count $=0,257<2,00$ on probability $=0,797>$ 0,50 is negative not significant. Determination variable to variable Regional Development Infrastructure is has standardized estimate of $0,247<0,50$ with CR idential to value $t$ count $=2,248>2,00$ on probability $=0,025<0,50$ significantly positive. Organization Resource variable determinan variable is the Regional Developmenthas standardized estimate amounted to $-0,224<0,50$ with $C R$ identical to the value $\mathrm{t}$-test $=-1,100<2,00$ on probability $=0,272>0,50$ not significant. Determination variable to variable investment Regional Developmenthas standardized estimate $0,927>0,50$ with $\mathrm{CR}$ identical to the value $\mathrm{t}$ count $=4,900>2,00$ on probability $=* * *<0,05$ is a significant positive.
\end{abstract}

Keywords: Geographical Location, Infrastructure, Organizational Resources, Investment and Regional Development

\section{Introduction}

\subsection{Background}

Batam is one of the islands among 329 islands of Riau Islands province. Which lies between the Malacca Strait and Singapore, there is only one literature that mentions the name Batam, the London Treaty which governs the division of territory between the Netherlands and the UK. However, according to the cruise from China, this island has been inhabited since $231 \mathrm{AD}$ where the population works as fishermen and farming. In the 1970's Batam began to be developed as a logistics and operational base for the oil and gas industry by Pertamina. Then based on Presidential Decree no. 41 of 1973, the development of Batam entrusted to a government agency called Batam Industrial Development Authority or now known as Batam Enterprises Agency (BP Batam). The Government of Indonesia makes Batam a Free Trade Zone and Free Port area through Government Regulation (PP) No. 46, 47, 48 the Year 2007 on the establishment of Free Trade Zone (KPBPB) Batam, Bintan \& around has been amended by PP No.5
Tahun 2011. To operationalize KPBPB Batam, Bintan, Karimun has been enacted Presidential Decree no. 9, 10 and 11 of 2008 on the Regional Board of KPBPB Batam, Bintan, Karimun as institutional form. The island of Batam with an area of $415 \mathrm{~km} 2$ is just $20 \mathrm{~km}$ at its closest point with Singapore separated by $15 \mathrm{~km}$ wide strait having a very strategic geographical position on international trade traffic lanes is a free trade area, part of Sijori region: Singapore, Johor (Malaysia) and Riau Islands (Indonesia). The government seizes opportunities by strategically taking advantage of Batam to become a place for the development of trade and industry which is full of technology, investment, home of collection and distribution of production, and international vessel traffic service center. Regarding geographical location, the area of Batam, Bintan, and Karimun (BBK) also has excellent potential.

\subsection{Formulation of the Problem}

Based on the description on the background, as described above, then the formulation of the problem in this study are:

1) What is the use of geography as a direct determination of investment? 
2) Is infrastructure a direct determination of investment?

3) What are organizational resources as direct determination of investment?

4) What is the use of geography as an indirect determination of regional development?

5) Is infrastructure an indirect determination of regional development?

6) What are organizational resources as indirect determination of regional development?

7) Is investment as a direct determination of regional development?

\section{Literature Review}

\subsection{Theory of Utilization Geographical Location of Free Trade Zone and Free Port (KPBPB).}

Rodrik (1) reveals that the use of geographical location will affect economic growth through two factors. First, the use of geographic area will change a country to be able to integrate with the global market, regardless of the policy of the state concerned. Further distance and isolated conditions will further increase the cost of integration. Second, geographic conditions will affect the institutional development side, primarily through the colonization of historical experiences built on geopolitical and natural resources through the existence of rent-seeking and rent distribution institutional behavior. Johansson and Nilsson (2), an exclusive economic zone is an area that is geographically and jurisdictive a region where free trade, including convenience and duty-free facilities on the importation of capital goods for export commodity raw materials, are opened widely.

MaxensiusTri et al. (3) theoretically, Special Economic Zones (SEZ) can be formed with three options:

1) KEK is created from a collection of bonded zones. Thus SEZ can also be termed as a bonded plus area.

2) SEZ is a collection of industrial areas given special treatment as a bonded area. This area may be a free trade zone if it is close to the port. The government is currently developing the concept of Sea Toll which is translated as pendulum of the archipelago stretching from West to East which forms a corridor of sea freight traffic from BelawanBatam-Jakarta-Surabaya-Makasar-Sorong, so that goods originating from the western region of Sumatra will be transported to the eastern area or otherwise will transit first in the port of Batam Island. In addition to the port, Batam will also be built shipbuilding industry, fishery industry, power plants, as well as the development of marine tourism. The Sea Toll will be integrated with land and air infrastructure, so the cost of transportation is cheap, logistics distribution is reasonable, and the prices related to basic needs will also decrease significantly. The Toll of Sea Tolerance is an effort to realize the first Nawacita that is to strengthen identity as a maritime state and the third Nawacita, which is to build Indonesia from the periphery by increasing the regions and villages within the framework of the unitary state. Also, the Tol Toll is also an affirmation, which the state is indeed present throughout the region through the ships that visited the area.

3) SEZ is a collection of bonded zones, industrial zones, and free trade areas.

\subsection{Infrastructure Theory.}

The Government through Presidential Regulation No. 42/2005 on the Committee for the Acceleration of Infrastructure Provision, describes several types of infrastructures whose provision is regulated by the Government, namely transport infrastructure, road infrastructure, irrigation infrastructure, drinking water and sanitation infrastructure, telematics infrastructure, electricity infrastruc- ture and oil and natural gas. Classification of the high support can be categorized as necessary infrastructure because nature is needed by the broader community, so it needs to be regulated by the government. Furthermore, according to MaxensiusTri et al., (3), there are three significant categories of infrastructure as follows: (1) Highways, Railways, Telecommunications, Ports, Bridges, Airports and so forth to support the operationalization of the area. (2) Availability of water source of 1 liter / second for each developed area hector, and (3) available power source and network system needed. Canning and Pedroni (4) argue that infrastructure has a plurality of externalities. Various infrastructures such as roads, education, health, etc., possess positive externalities, providing support that the facilities provided by multiple foundations are positive externals that can increase the productivity of all inputs in the production process. Positive externalities in infrastructure include Spillover Effect in the form of increased production of the company and the agricultural sector without raising the capital and labor inputs, as well as increasing the level of technology. Ndulu et al., (27) Infrastructure is the driving force of economic growth, Inadequate infrastructure is one of the critical obstacles to faster economic growth. Research (5) prove that foundation has a substantial impact on economic growth. The results of this study support what is found by (6) that infrastructure is statistically significant to affect the output.

\subsection{Organization Resource Theory.}

Wong et al., (7) in MaxensiusTri et al., (3) revealed that another critical aspect that needs attention in KPBPB is Bureaucratic efficiency. The flexibility of the bureaucracy must be strengthened to keep pace with the rapid pace of business dynamics. One of the classic problems often encountered in implementing KPBPB in other countries is the inefficiency and inflexibility of the bureaucracy. For example, lack of coordination between departments, the division of tasks and authority and unclear responsibilities, and attract the interest of various elements of administration. The preconditions needed to support KPBPB, in this case, is the presence of functional governance which is implemented with streamlined and efficient bureaucracy and compatible with business dynamics. Wibowo (9) states that every organization has its own culture that is different from other organizations. The organizational culture reflects the general perception made by all members of the organization, Kreitner et al., (9) exhibit corporate culture characteristics as follows: (1) Organization may have a dominant culture and several different subcultures. (2) Organizational culture tends to change over time. (3) All religions have positive and negative aspects; some organizations can be successful when they have a particular culture even though they may not be compatible with other organizations. Jerome (10) states that organizational culture is a collective belief system that people have in the organization about their ability to compete in the market, and how they act in the belief system to provide value-added products and services in the market for rewarding financial rewards Organizational culture is expressed through the attitudes, belief systems, dreams, behaviors, values, ordinances of the company, and primarily through the actions and performance of workers and management.

\subsection{Investment Theory.}

Investment is a commitment to some funds or other resources to obtain some future benefits. Finance is also the expense of the company to buy or get the factors of production that will be used by the company to produce goods or services. Or expenditures to purchase production factors to build the business and to maintain the survival of the company. Tandelilin Eduardus (11). Investment There are two kinds: (1) Autonomous Investment (Fixed Investment). (2). Innocent Investments. Fixed investment is an investment that does not depend on the amount of income. Encouraged investment is an investment that depends on income. Fixed investment is generally used to obtain adjusted production factors 
such as machinery, buildings, land, / investments to set up a business. The investment-driven investment whose size depends on national income means that if income increases then investment will increase as well. Finance is also a long-term investment in the hope of earning future profits as a professional compensation for consumption delays, the effects of inflation and risk borne. The parties who do the investment activities are called investors. Investors, in general, can be classified into two, namely individual investors (individual / retail investors) and institutional investors (institutional investors). Individual investors consist of individuals who engage in investment activities. While institutional investments usually include insurance companies, depositors (banks and savings and loan institutions), pension funds, and investment companies. Investment decisions can be made by individuals, from these investments which can be capital gain/loss and yield.

\subsection{Theory of Economic Growth.}

Economic Growth is a term used to describe the development of productive financial capacity. Commonly used measures are growth rates in Gross National Product (GNP) and Gross Domestic Product (GDP) Joseph et al., (12). Rostow (13) in Ernan Rustiadi et al., (14) sparked a model of the stage of economic growth. Growth can be divided into five growth stages: (1) Traditional society, (2) Precondition for take-off, (3) Take-off, (4) Movement towards maturity (the drive to maturity), (5) High consumption period (the age of high mass consumption).

Gujarat (15) States that economic growth can be defined as a process of changing a country's economic conditions on a sustainable basis to a better state for a specified period. Economic growth can also be interpreted as a process of increasing the production capacity of an economy embodied in the form of an increase in national income. Their economic growth is an indication of the success of economic development. How to Measure The economic growth of a country can be measured by comparing the current year's Gross National Product (GNP) with GNP the previous year.

\subsection{Theory of Regional Development.}

Ernan Rustiadi et al., (14), Understanding the region is significant to note when talking about development programs related to regional development and regional development. Development of areas associated with the development of specific functions of a geographical unit, including social, economic, cultural, political and defense and security functions. In the meantime, a regional event should have a broader scope of studying inter-regional linkages. The planning and development areas may include political (central or local) administrative regions as well as functional areas of planning. Murty (16) defines the territory as a geographical territorial or place area, which can take the form of a state, state, province, district, and countryside. But a region, in general, does not merely refer to a place or area, but rather an economic, political, social, administrative, climatic to geographical unity, by the development objectives. Riyadi et al., (17), Regional planning and development is a development planning process intended to make changes towards a better event for a community, government and environment within a particular region, by utilizing or utilizing various resources exist, and must have a fully fledged, complete orientation, sticking to the priority principle. According to Archibugi (18), the theory of Regional Planning can be divided into four components namely Physical Planning, Macro-Economic Planning, Social Planning, and Development Planning (Development Planning). Regional planning and development are expected to produce urban spatial arrangement with the allocation of urban space by its distribution, so that civic space activity goes along with economic growth.

\subsection{Conceptual Framework.}

The conceptual framework for this research using survey method, this research using correlation technique because this research was trying to investigate the causality relationship between several research variables. The variables are differentiated into independent variables (independent variable) that are variable that influence, consist of (X1) Geographical location, (X2) Infrastructure, (X3) Organizational Resources. Another variable is the dependent variable (dependent variable) that is the variable that is affected or the result due to the independent variables. In this research, there are two dependent variables: Mediating variable (moderating variable) is (Y) Investment, and the dependent variable is (Z) Regional Development. Correlation study using correlation and regression analysis, where the three independent variables (X1, X2, X3,) are connected to the dependent variable $(\mathrm{Y})$ and $(\mathrm{Z})$ with the concept of thinking framework can be described as follows:

Figure 1: Conceptual framework.

\subsection{Hypothesis}

The relationship between variables that need to be verified or tentative (temporary) statements that are conjectures or guesses about what researchers observe in an attempt to understand them. A hypothesis should show a clear structure so it is easy to know the type of variable and the direction of the relationship between variables, whether positive or negative, whether significant or not significant. From the formulation of the observed problem, the theoretical basis and conceptual framework can be modeled as research hypotheses as follows:

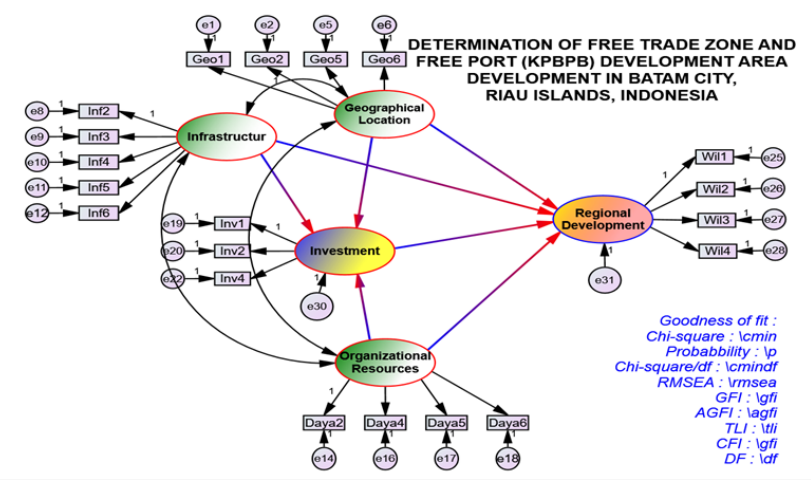

Hypothesis 1: (H1): H1: $\mathrm{Y}=\gamma_{\mathrm{y} \cdot \mathrm{x} 1} \mathrm{X}_{1}+\mathrm{e} 1, \quad \rightarrow$ Direct Effects Geographical Location $\left(\mathrm{X}_{1}\right)$ to Investment $(\mathrm{Y})$.

Hypothesis 2: (H2): H2: $Y=\gamma y \cdot x_{2} X_{2}+$ e1 $\rightarrow$ Direct Effects Infrastrutur $\left(\mathrm{X}_{2}\right)$ to Investment $(\mathrm{Y})$.

Hypothesis 3 (H3): H3: $\quad Y=\gamma y \cdot x_{3} X_{3}+$ e1 $\rightarrow$ Direct Effects Organizational Resources $\left(\mathrm{X}_{3}\right)$ to Investment $(\mathrm{Y})$.

Hypothesis 4 (H4): H4: $Z=\gamma Z_{1} \cdot x_{1} X_{1}+$ e2 $\rightarrow$ Direct Effects Geographical Location $\left(\mathrm{X}_{1}\right)$ to Regional Development $(\mathrm{Z})$

Hypothesis 5 (H5): H5: $Z=\gamma$ Z. $x_{2} X_{2}+$ e2 $\rightarrow$ Direct Effects Infrastructure $\left(\mathrm{X}_{2}\right)$ on Regional Development $(\mathrm{Z})$

Hypothesis 6 (H6): H6: $\quad Z=\gamma z \cdot x_{3} X_{3}+$ e2, $\rightarrow$ Direct Effects Organization Resource Resources $\left(X_{3}\right)$ on Regional Development (Z).

Hypothesis 7 (H7): H7: $\quad Z=\beta z y Y_{1}+e 2, \quad \rightarrow$ Direct Effects Investment (Y) on Regional Development (Z).

\section{Research Methodology.}

The variables are differentiated into independent variables (variables that influence, consisting of $\left(\mathrm{X}_{1}\right)$ Utilization of Geographical Location, $\left(\mathrm{X}_{2}\right)$ Infrastructure, $\left(\mathrm{X}_{3}\right)$ Organizational Resources. Another variable is the dependent variable that is the variable that is influenced or the result due to the independent variables. In this 
research, there is two dependent variable that is intermediate variable is (Y) Investment, and the dependent variable is (Z) Development Area. This research is survey research, that is research that takes the sample directly from a population. Judging from the problem under study, this research is also Causality research, which aims to analyze the relationship and influence (causation) of two or more phenomena through hypothesis testing. Cooper et al., (19) revealed that research based on the theory or hypothesis that will be used to test a phenomenon that occurs is classified on the type of critical research. Explanatory research studies the relationship between two or more variables, then attempts to explain the phenomenon that occurs.

The population is a collection of all objects to be measured in research Cooper et al., (19). Population in this research is employees of Batam Area Entrepreneur Body (BP Batam), Apindo, BKPM, Batam City Government Employee, Kadin, Society, and Student. The amount of population sampled is planned as follows: (a) BP BP employees as many as 60 people. (b) BKPM of 30 persons. (c) Indonesian Chamber of Commerce as many as 15 people (d) APINDO as many as 15 people. (e) Public Society as many as 40 people. (e) There are 15 students. (f) Municipal Government employees 15 persons. The sampling technique used included in the category of non-probability sampling (Sekaran (20); Black et al., (21); Cooper et al., (19). The selected non-probability sampling technique is a judgmental (purposive) technique. This technique is chosen to ensure that only samples have specific elements that have been determined by the researcher to be sampled Black et al., (21).

Cooper et al., (19), Sample is the population element selected to represent the population in the study. In this study, the sample size with the number of respondents 190 respondents adjusted with the analysis model used is Structural Equation Model (SEM). In this regard, the sample size for SEM using the Maximum Likelihood Estimation (MLE) estimation model is 100-200 samples or as much as 5-10 times the estimated number of parameters (22).

The main instrument in this study is the questionnaire. Variable measurements were performed using the Likert scale. Respondents were asked to state the level of approval of the statement proposed by the researcher by perceptions of each respondent. The answer consists of five options, namely: Strongly Disagree (STS), Disagree (TS), Agree (CS), Agree (S), and Strongly Agree (SS). Criteria for validity testing is by comparing hitting with a label, at a significant level of $95 \%$ or $=5 \%$. The question item is called valid if the item has rhitung > standard $=0.30$. In this case, the intended rating for each item of the question is the product moment correlation coefficient between the score of each item with the total score of all items denoted by Corrected Item-Total Correlation on the calculation of SPSS program for each question item of a variable. Singgih (23). To test the reliability of a questionnaire from a research variable Cronbach's Alpha Coefficients are used. The magnitude of the Cronbach's Alpha Coefficient shows the level of Reliability of the list of questions. The calculation of moment product correlation and Cronbach's Alpha Coefficient is done with SPSS for Windows version 22.0 special sub-menu Scale on Analyze menu. Data analysis was done by using Structural Equation Model (SEM) technique. The software used for structural analysis is AMOS 22 and from Arbuckle and for descriptive study using SPSS 22 .

\section{Research Result and Discussion.}

The research entitled "Determination of Free Trade Zone and Free Port (KPBPB) Development Area Development in Batam City" was conducted not to produce a model, but intended to confirm hypothetical model through empirical data, from each responden who asked to answer the questionnaire, to test the validity and reliability of the survey. If the census has been tested validly and reliabiltynya, then the problem is not valid, and no credibility is removed from the questionnaire, the respondent's answer is tabu- lated with Microsoft Excel. The empirical data is then processed with Amos for Windows version 22.0 for the normality test, Confirmatory Factor Analysis (CFA) and influence test with SEM based on assumptions in Structural Equation Modeling (SEM) to test model feasibility.

\subsection{Evaluation of SEM Assumptions.}

Assessment of sem assumptions is preceded by an assessment of normality to know the normality of data. Normality data analysis is used to find out whether the data obtained and collected have normal distribution or not. For data normality analysis used the critical value of skewness and kurtosis value. Analysis of the distribution of normality is necessary if the amount of data (n) $<100$ pieces Nunnally et al., (24). For the evaluation of normality, skewness and kurtosis tests were performed. Skewness test is used to look at data dissemination slope, while kurtosis to see the tilting of data dissemination, Suharyadi (25), normality test is done on data of each indicator of the latent variable, that is variable data of geographical location Utilization, Infrastructure, Organizational Resources, Investment and Area Development. Based on the results of the Condos- signatory Factor Analysis (CFA) program Amos Version 22.0 for Windows against research data for each latent variable.

\subsection{Testing Results Confirmatory Factor Analysis (CFA).}

Ferdinand (26) Confirmatory factor analysis is used to test the unidimensionality of the dimensions that explain the latent variables of the model, whether all the indicators used in the study are the possible variable formation of geographical location, infrastructure, organizational resources, investment and regional development. Confirmation factor analysis is also intended to analyze the level of validity of the existing data in this study. That is, whether the indicators used have meaningful enough to define the latent variables formed.

\subsection{Determination Analysis with SEM.}

In accordance with the purpose of research to determine the influence of Geographic Location, Infrastructure, Organizational Resources, and Investment to Regional Development, the data analysis is done with Full Model Structural Equation Modeling (SEM), using AMOS for windows version 22.0 software for testing a relatively complex set of relations simultaneously until Regression Weights are obtained. The hypotheses tested are:

1. Hypothesis $1(\mathrm{H} 1)$ : Utilization of Geographical Location as a determinant directly (direct) to Investment.

2. Hypothesis $2(\mathrm{H} 2)$ : Infrastructure as a determinant directly (direct) to Investment.

3. Hypothesis3 (H3) : Resource Organization, as a determi nant directly (direct) to Investment

4. Hypothesis $4(\mathrm{H} 4)$ : Utilization of Geographical Location as Indirect Determinant (Indirect) to Regional Development.

5. Hypothesis $5(\mathrm{H} 5)$ : Infrastructure as the indirect determinant (Indirect) to Regional Development

6. Hypothesis 6(H6) : Organization Resources, as Indirect determinants to Regional Development.

7. Hypothesis $7(\mathrm{H} 7)$ : Investment as a determinant directly (direct) to Regional Development.

\subsection{Analysis of Measurement Model Test with Lamda} Parameters $(\lambda \mathbf{i})$.

Test parameters lamda $(\lambda \mathrm{i})$ aims to determine the validity of each research indicator by using the value of standardized estimate (regression weight) in the form of loading factor. If the value of standardized estimate regression weight $(\operatorname{lambda}(\lambda \mathrm{i}))>0.50, \mathrm{CR}$ value $>_{\text {table }}=2.00$, and Probability $<\alpha=0,05$, then the loading 
factor of lambda $((\lambda \mathrm{i})$ parameter is stated significant (Ferdinand, (26)

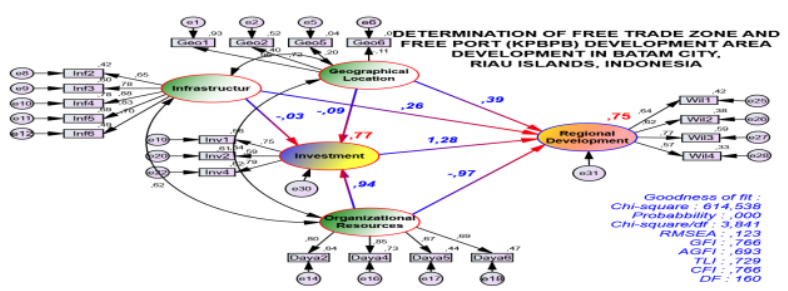

Figure 2: Full Model (Standardized) Variable Utilization Geographical Location, Infrastructure, Organizational Resources, Investment, and Regional Development.

\subsection{Structural Equation Model Analysis.}

Model Tests for Geographical Use $\left(\mathrm{X}_{1}\right)$, Infrastructure $\left(\mathrm{X}_{2}\right)$, Organizational Resource $\left(\mathrm{X}_{3}\right)$, Investment $(\mathrm{Y})$ and Regional Development (Z) variables based on the calculation of Standardized Regression Weight (Lamda) and regression weight can be made table output as presented in table 1 and table 2. Below

Table 1 :Standarized Regression Weight

Table 2 : Regression Weight (Lamda ( $\square \mathrm{i})$ )

\begin{tabular}{|c|c|c|c|c|c|c|c|c|c|c|c|c|}
\hline & & & Estimate & & & & & Estimate & S.E. & C.R. & P & Label \\
\hline INV & $<--$ & DAYA & 0,972 & & INV & $<-$ & DAYA & 1,278 & 0,17 & 7,336 & $* * *$ & par_5 \\
\hline INV & $<--$ & GEO & 0,121 & & INV & $<-$ & GEO & 0,155 & 0,09 & 1,749 & 0,080 & par_6 \\
\hline INV & $<--$ & INFR & $-0,186$ & & INV & $<-$ & INFR & $-0,26$ & 0,13 & 2,013 & 0,044 & par_24 \\
\hline WIL & $<--$ & GEO & 0,02 & & WIL & $<-$ & GEO & 0,02 & 0,08 & 0,257 & 0,797 & par_1 \\
\hline WIL & $<--$ & INV & 0,927 & & WIL & $<-$ & INV & 0,732 & 0,15 & 4,900 & $* * *$ & par_2 \\
\hline WIL & $<--$ & DAYA & $-0,224$ & & WIL & $<-$ & DAYA & $-0,233$ & 0,21 & 1,100 & 0,272 & par_3 \\
\hline WIL & $<--$ & INFR & 0,247 & & WIL & $<-$ & INFR & 0,272 & 0,12 & 2,248 & 0,025 & par_4 \\
\hline
\end{tabular}

From the table of Standardized Regression Weight (Lamda) and Regression Weight (Lamda) above can be seen that not all indicators of latent variables have standardized estimate (regression weight) in the form of loading factor or lambda $(\lambda i)>0,50$, critical value $\mathrm{CR}>2,00$ and has a probability $<\alpha=0,05$. Thus it can be said that not all indicators of these latent variables are significant.With the Amos for Windows version 22.0 statistical program for Normality test, CFA and influence test with SEM based on assumptions in Structural Equation Modeling (SEM) to test model feasibility, the results of this research analysis are as follows:

The influence of latent variable Geographical Utilization (GEO) to latent variable Investment (INV) has standardized estimate (regression weight) of 0.121 with CR (Critical Ratio = identical to t-count value), $\mathrm{CR}=1,749<2.000$ and Probability $=0,080>\alpha=$ 0,05 indicates that the influence of latent variable Geographical Usage (GEO) to latent variable of Investment (INV) is negative (untested) and not significant.

Influence of latent Infrastructure (INFR) variable to latent variable Investment (INV) has standardized estimate (regression weight) of -0.186, with CR (Critical Ratio = identical to t-value), CR -2.013 $<2,00$ and Probability $=0.044 \leq \alpha=0,05$, indicates that the influence of Infrastructure latent variable (INFR) to investment latent variables (INV) is negative (untested) but significant.

The influence of latent variable Organizational Resource (DAYA) to latent variable Investment (INV) has standardized estimate (regression weight) of 0.972 with CR (Critical Ratio = identical with t-value), $\mathrm{CR}=7,336>2,000$ and Probability $=* * *<\alpha=$ 0.05 indicates that the influence of latent variable Resource Organization (DAYA) to investment latent variables (INV) is positive (tested truth) and significant.

The influence of latent variable Geographical Use (GEO) to latent variables of Regional Development (WIL) has standardized estimate (regression weight) of 0,020 with $\mathrm{CR}$ (Critical Ratio = identical to t-count value), CR value $0.257<2,000$ and Probability $=0.797>\alpha=0.05$ indicates that the influence of latent variable Geographical Usage (GEO) to latent variables of Regional Development (WIL) is negative (untested) and not significant. The influence of Infrastructure latent variables (INFR) to latent variables Regional Development (WIL) has standardized estimate (regression weight) of 0.247 , with CR (Critical Ratio = identical to t-value), CR 2,248 $>2,000$ and Probability $=0.025<\alpha=0.05$ indicates that the influence of Infrastructure latent variables (INFR) to latent variables Regional Development (WIL) is positive (tested) and significant.
The influence of latent variable of Organizational Resource (DAYA) to latent variable of Regional Development (WIL) has standardized estimate (regression weight) equal to - 0,224, with $\mathrm{CR}$ (Critical Ratio = identical with t-value), $\mathrm{CR}-1,100<2,000$ and Probability $=0,272>\alpha=0.05$ indicates that the influence of latent variable Resource Organization (DAYA) to latent variable Development of Region (WIL) is negative (untested) and not significant.

The influence of latent variable Investment (INV) to latent variable Development of Region (WIL) has standardized estimate (regression weight) of 0.927 , with CR (Critical Ratio = identical to t-value), CR 4,900 > 2,000 and Probability $=* * *<\alpha=0.05$ indicates that the influence of investment latent variable (INV) to the latent variable of Regional Development (WIL) is positive (testable) and significant.

Taking into account the standardized estimate (Group number 1 Default model) for Geographical Location (X1), Infrastructure (X2), Organizational Resources (X3), Investment (Y)) variables, to Regional Development $(\mathrm{Z})$ :

$\mathrm{H}_{1:} \mathrm{Y}=\gamma_{\mathrm{y} \cdot \mathrm{x} 1} \mathrm{X}_{1+} \mathrm{e}_{1}=0,121 \mathrm{X}_{1+} \mathrm{e}_{1}$

$\mathrm{H}_{2}: \mathrm{Y}=\gamma_{\mathrm{y} . \mathrm{x} 2} \mathrm{X}_{2+} \mathrm{e}_{1}=-0,186 \mathrm{X}_{2+} \mathrm{e}_{1}$

$\mathrm{H}_{3}: \mathrm{Y}=\gamma_{\mathrm{y} . \mathrm{x} 3} \mathrm{X}_{3+} \mathrm{e}_{1}=0,972 \mathrm{X}_{3}+\mathrm{e}_{1}$

$\mathrm{H}_{4}: \mathrm{Z}=\gamma_{\mathrm{z} . \mathrm{x} 1} \mathrm{X}_{1+} \mathrm{e}_{2}=0,020 \mathrm{X}_{1+} \mathrm{e}_{2}$

$\mathrm{H}_{5}: \mathrm{Z}=\gamma_{\mathrm{z} . \mathrm{x} 2} \mathrm{X}_{2+} \mathrm{e}_{2}=0,247 \mathrm{X}_{2+} \mathrm{e}_{2}$

$\mathrm{H}_{6}: Z=\gamma_{\mathrm{z} . \mathrm{x}} \mathrm{X}_{3+} \mathrm{e}_{2}=-0,224 \mathrm{X}_{3+} \mathrm{e}_{2}$

$\mathrm{H}_{7}: \mathrm{Z}=\beta_{\text {z.y }} \mathrm{Y}_{+} \mathrm{e}_{2}=0,927 \mathrm{Y}_{+} \mathrm{e}_{2}$

\subsection{Analysis of Goodness of Fit.}

Based on test criteria, Chi-square $\left(\chi^{2)}\right.$, Relative Chi-square $\left(\chi^{2} / \mathrm{df}\right)$, RMSEA, GFI, AGFI, TLI, and CFI and Goodness of Fit Amos for windows version 22.0 can be made Evaluation of Goodness of fit as the following table 3 .

Considering the value of cut-of-value and goodness of fit model results in Table 4.5 shows all unmet criteria of 8 (eight) criteria used. Relative Chi-square $\left(\chi^{2} / \mathrm{df}\right)$ criteria are not met while the marginal ones are only TLI and CFI. Since only two are marginal of the eight required criteria, the above model can be expressed as a bad model. For that, we need to do the modification by correlating between errors that have Modification Indek (M.I.) $>8.00$ to improve the Goodness of fit table 3 Analysis of Measurement Models with Determination. 
Table 3: Evaluation of the Goodness of Fit

\begin{tabular}{|l|l|l|l|}
\hline A goodness of Fit Index & Cut-off Value & Model Results \\
\hline Chi-square $(\chi 2)$ & Expected Small & 1696,997 & Information \\
\hline Rel additive Chi-square $(\chi 2 / \mathrm{df})$ & $\leq 3,00$ & 5,404 & Not good \\
\hline Probability & $>0,05$ & 0,000 & Not good \\
\hline RMSEA & $\leq 0,08$ & 0,153 & \\
\hline GFI & $\geq 0,90$ & 0,642 & Not good \\
\hline AGFI & $\geq 0,90$ & 0,569 & Not good \\
\hline TLI & $\geq 0,94$ & $0,642+)$ \\
\hline CFI & $>0,94$ & $0,642+)$ \\
\hline
\end{tabular}

*) Meet the Goodness of fit

+) Marginal

Table 4: Squared Multiple Correlations (Group number 1 - Default model)

\begin{tabular}{|c|c|c|c|}
\hline & & \\
\hline INV & & & Estimate \\
\hline WIL & & & 0,773 \\
\hline
\end{tabular}

Source: Analysis with SEM

Square Multiple Correlation whose respective values for Investment $(\mathrm{INV})=0.773$, for Regional Development $(\mathrm{WIL})=$ 0.802. According to Ferdinand (26) Square Multiple Correlation value for investment variable (INV) $R^{2}=0.773$ is identical with $R^{2}$ in SPSS of 0.773 then the amount of investment variable determination $(\mathrm{INV})=0.773 \times 100 \%=77.30 \%$. Thus it can be stated that the change of investment is influenced by the Utilization of Geographic Location, Infrastructure and Organizational Resources of 77.30\%.For determination of variable Development Area (WIL) $\mathrm{R}^{2}=0.802 \times 100 \%=80.20 \%$. Thus it can be stated that the change of Regional Development is influenced by the Use of Geographic Location, Infrastructure, Organizational Resources, and Investment of $80.20 \%$. Judging from the structural equation model above shows Regression Weight $(\gamma)$, there are three variables whose influence is positively significant, the three variables are negative and not significant, signs are Chi-square, Relative Chi-square $\left(\chi^{2} / \mathrm{df}\right)$, RMSEA, GFI, TLI, and CFI. When viewed from Regression Weight exogenous variables to endogenous variables turned out in the modification model, there is an increase in the six regression coefficients (Standardized Regression Weight), and the other two are and one variable is negative but significant. From the Evaluation of Goodness of Fit shows one fulfilled criterion (Chi-square/df) and two marginal namely, TLI and CFI of the eight criteria. Thus, the model cannot be expressed as a good model (not yet fulfilling the Goodness of fit), and it is deemed necessary to modify the model to improve the fit of the model (Goodness of fit. To improve the value of Goodness of fit can be done by not including the indicator that has the coefficient of Standardized Regression Weight between indicator $\lambda$ (loading factor) small or by correlating some indicator that has the value of Modification Index (M.I) big Ferdinand, (26). Then this research is deemed necessary to hold further modifications.

When viewed from the Goodness of fit, seen modified model shows improvement on six indicators of the eight indicators available. The primary model that initially had one symbol meets the Goodness of fit and the two marginal, into six qualified marginally close to a predetermined value. From the above analysis, it can be stated that by modifying the model can improve the Goodness of fit. Since six indicators meet the requirements of the goodness of fit, then the model has been considered useful (good of fit) hence no longer need to make further modifications.

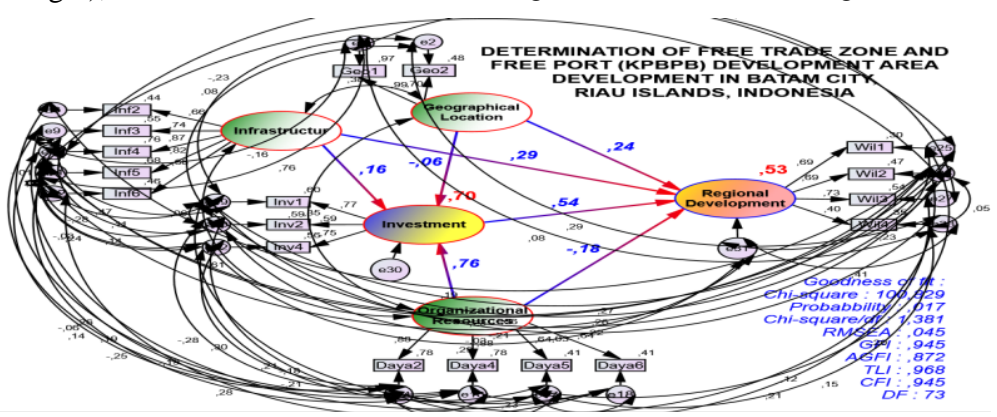

Figure 3: Modified Full Models (standardized) Modification Models-2 Utilization of Geographical Location, Infrastructure and Organizational Resources, Investment and Regional Development

Table 5: Comparison of Main Model with Modified-1 and 2 Results

\begin{tabular}{|c|c|c|c|c|c|}
\hline Goodness of Fit Index & Cut-off Value & Model results & $\begin{array}{l}\text { Modified } \\
\text { Models-1 }\end{array}$ & $\begin{array}{l}\text { Modified } \\
\text { Models-2 }\end{array}$ & Information \\
\hline Chi-square $\left(\chi^{2}\right)$ & Expected Small & 1696,997 & 1114,532 & $100,829 *)$ & Good \\
\hline Relative Chi-square ( $\chi 2 / \mathrm{df})$ & $\leq 3,00$ & 5,404 & 3,98 & $1,381 *)$ & Good \\
\hline Probability & $>0,05$ & 0,000 & 0,000 & $0,017+)$ & Marginal \\
\hline RMSEA & $\leq 0,08$ & 0,153 & 0,126 & $0,045 *)$ & Good \\
\hline GFI & $\geq 0,90$ & 0,642 & 0,741 & $0,945 *)$ & Good \\
\hline AGFI & $\geq 0,90$ & 0,569 & 0,651 & $0,872+)$ & Marginal \\
\hline CFI & $>0,94$ & $0,642+)$ & $0,741+)$ & $0,945 *)$ & Good \\
\hline
\end{tabular}

Code of Conduct:

*) Meets the Goodness of fit

+) Marginal 


\section{Conclusions and Suggestions}

\subsection{Conclusion}

Based on the analysis of research variables responded by respondents consisting of BP Batam officials, BKPM employees, members of the Indonesian Chamber of Commerce (KADIN), members of the Employers' Association of Indonesia (APINDO), Students and Community Leaders, were analyzed by the Amos for Windows statistics program version 22.0 for Normality test, Confirmatory Factor Analysis (CFA) and determination test using Structural Equation Modeling (SEM) program, based on assumptions in SEM to test model feasibility, it can be concluded as follows:

Determination of latent variable Geographical Utilization to latent variable Investment is negative (untested truth) and not significant. This means that the latent variable Geographical Usage Utilization tested is not significant, or in other words in the case of correlation, the degree of correlation between Geographical Utilization latent variable and investment latent variables has no significant effect on the $95 \%$ confidence level.

Determination of Infrastructure latent variables to latent variables Investment is negative (untested truth) but significant. This means that the potential variable of Infrastructure tested is substantial, but in the case of correlation, the relationship between Infrastructure variables and investment latent variables has no significant effect on the $95 \%$ confidence level.

Determination of latent variable Organizational Resource to potential variable Investment is affirmative (tested truth) and significant. This means that the hidden variable of Organizational Resource tested is substantial or in other words in the case of correlation, the level of relationship between the Organizational Resource variable and the latent investment variable has a significant effect on the $95 \%$ confidence level.

Determination of latent variables Geographical Utilization to latent variables Regional Development is negative (untested truth) and not significant. This means that the potential variable of Geographical Utilization tested is not substantial or in other words in the case of correlation, the level of relationship between latent variables Geographical Utilization with a latent variable of Regional Development has no significant effect on the 95\% confidence level.

Determination of Infrastructure latent variables to latent variables Regional Development is positive (tested truth) and significant. This means that the potential variable Infrastructure tested substantial or in other words in the case of correlation, the level of relationship between Infrastructure variables with the latent variable Development of Region had a significant effect on the 95\% confidence level.

Determination of latent variable Organizational Resource to potential variable Regional Development is adverse (untested truth) and not significant. This means that the hidden variable of Organizational Resource tested is not substantial, in the case of correlation between the Organizational Resource variable with the latent variable Regional Development has no significant effect on the $95 \%$ confidence level.

Determination of latent variables Investments to latent variables Regional Development is positive (tested truth) and significant. This means that potential investment variables tested substantial or in other words in the case of correlation, the level of relationship between investment variables with latent variables Regional Development significant effect on the level of confidence $95 \%$.

\subsection{Suggestion}

Geographical location for latent variables Investment, need to be improved where Batam excess because a geographic area is an archipelagic region adjacent to the international shipping line, also adjacent to neighboring Singapore and Malaysia, besides not maximizing the position of beach and marine to increase investment.

Infrastructure development in the city of Batam should be oriented to investment, not merely adapted to a social community to happen balance of infrastructure develop

Cooperation between Batam City Government and Batam Development Board (BP) in synergy when needed to attract investors into Batam regarding easy administration, bureaucracy, and land clearance.

Geographical Utilization latent variable to the latent variable of Regional Development. Regional Development in Batam City must be able to support the growth of the development of Batam City thoroughly, through the development of industrial activities, trade and services and the arrangement of locations in an integrated, harmonious, aligned, balanced, in accordance with the potential of Natural Resources and the carrying capacity of the region, ensure the balance and harmony of the environment with the principle of sustainable development that is environmentally friendly. It is necessary to build and maintain modern and integrated laborintensive infrastructure networks such as roads, electricity, water, information \& communication technology, ports etc., in the planning and development of areas that are expected to produce urban spatial arrangements with appropriate municipal space allocation with its designation such as downtown area, industrial area, lowclass, middle and high class settlement, and development area, so that urban space activity goes along with economic development of Batam city to better.

\section{References}

[1] Rodrik, D. (2001).'Introduction What Do We Learn From Country Narratives', in Dani Rodrik (ed), in Search of Prosperity, Princeton, Uni Press?

[2] Johannsson, Helena, and Nilsson. (1997). 'Export Processing Zones as Catalyst', World Development, Vol.25, No.12

[3] Maxensius Tri Sambodo \& Sayrif Hidayat. (2007). Counting Opportunities Considering Reality. The Center for Economic Research of the Indonesian Institute of Sciences in collaboration with Batam City Government of Kepulauan Riau Province.

[4] Canning, David, and Peter Pedroni, (2004). Infrastructure and LongRun Economic Growth. The University of Belfast.

[5] Esfahani, H. S., and Remirez, M. T. (2003). Institutions, Infrastructure, and Economic Growth. Journal of Development Economic, 70:443-477.

[6] Aschauer, D. A. (1989). Is Public Expenditure productive? Journal of Monetary Economics,(23):177-200. Batam City Spatial Plan Year 2004-2014.

[7] Wong, K.Y. and the Chu, David, K.Y.,(1985).' Export Processing Zones and Special Economic Zones as Locomotives of Export-led Economic Growth, in K.Y. Wong and K.Y Chu (eds), Modernization in China. Oxford: Oxford University Press.

[8] Wibowo.(2010). Organizational Culture A Necessity To Improve Long-Term Performance. Jakarta: Rajawali Press.

[9] Kreitner, Robert and Angelo Kinicki. (2001). Organizational Behavior, New York: McGraw-Hill Higher Education.

[10] Jerome W..(2006). Corporate Culture. New York: St. Martin's Press

[11] Tandelilin Eduardus. (2001), Investment Analysis and Portfolio Management, BPFE-Yogyakarta, Member of IKAP No-003, Yogyakarta

[12] Joseph G.Nellis, David Parker, The Essence of The Economy: Prentice Hall International (UK) Ltd, 1990.

[13] Rostow, W.W. (1960). The Stages of Economic Growth. A nonCommunist Manifesto. Cambridge University Press.

[14] Ernan Rustiadi, Sunsun Saeful Hakim dan Dyah, R.Panuju. (2011), Regional Planning and Development, second edition: Crestpent Press dan Yayasan Pustaka Obor, Jakarta.

[15] Gujarat, Damodar N. (2004). Basic Econometrics, $4^{\text {th }}$ ed., Mc GrawHill New York.

[16] Murty, S,(2000), Regional Disparities: Need and Measure for Balanced Development in Regional Planning and Sustainable Devel- 
opment, Shukla, A (Ed.). Kanishka Publishers, Distributors, New Delhi-110-002

[17] Riyadi dan Bratakusumah.D.S. (2003). Regional Development Planning: Strategies to Explore Potential in Achieving Regional Autonomy, Gramedia Pustaka Utama, Jakarta.

[18] Archibugi.F. (2008). Planning Theory, From the Political Debate to the Methodological Reconstruction.

[19] Cooper and Schindler, (2013), Business Research Methods; 12th Edition.Publisher, McGraw-Hill

[20] Sekaran, (2006), Research Methodology For Business, Issue 4 Book 2, Penerbit Salemba, Jakarta.

[21] Black, J. A., \& D. J. Champion. (2001). Methods and problems of social research. Bandung: Refika Aditama.

[22] Ghozali, Imam.,(2004). Application of multivariate analysis with SPSS program, Semarang: Badan Penerbit Universitas Diponegoro.

[23] Singgih Santoso (2007). Structural Equation Modeling Concept and Applications with AMOS, Jakarta: Elex Media Komputindo

[24] Nunnally and Sujana in Husaini Usman, (1992): Introduction to Statistics, Issue 2, Bumi Aksara, Jakarta.

[25] Suharyadi, (2003): Statistics For Modern Economy and Finance, Volume 1, Penerbit Salemba Empat, Jakarta.

[26] Ferdinand, Augusty. (2002). Structural Equation Modeling in Management Research. Issue 2. Semarang: BP. UNIP

[27] Ndulu, Benno, Kritzinger-van Niekerk and Reinikka. (2005). Infrastructure, Regional Integration, and Growth in Sub-Saharan Africa. The National, [1]Regional and International Challenges Fonda. The Hague, December 2005:101-121.

\section{Missing in Document}

[1] Central Bureau of Statistics Batam, Batam In Figures Year 2017.

[2] Familoni, K. A. (2004). The Role of Economic and Social Infrastructure in Economic Development: A Global View.

[3] Government Regulation of the Republic of Indonesia Number 46 the Year 2007, Concerning Determination of Batam as Free Trade Zone and Free Port.

[4] http://www.wikipedia.org/SEZ

[5] Regulation of the President of the Republic of Indonesia Number 33 the Year 2010, Concerning the National Council and the Council of SEZ Regions

[6] Rustiadi, E., D.R Panuju, B.H.Trisasongko, dan I, Carolina. (2003) Development of Spatial Classification Model as a Zoning Method Integrated Superior Research Report 2002-2003, National Research Council (DRN) -LIPI with Research Institute IPB

[7] Tri Widodo.(2006). Development Planning, UPP, Yogyakarta. 